\title{
Earnings Response Coefficients and Default Risk: Case of Korean Firms
}

\author{
Yohan $\mathrm{An}^{1}$ \\ ${ }^{1}$ Department of Finance and Accounting, Tongmyoung University, Busan, South Korea \\ Correspondence: Dr. Yohan An, Assistant Professor, Head of Department, Department of Finance and Accounting, \\ Tongmyoung University, Busan, South Korea. E-mail: accahn@tu.ac.kr
}

Received: February 26, 2015

Accepted: March 16, 2015

Online Published: March 30, 2015

doi:10.5430/ijfr.v6n2p67

URL: http://dx.doi.org/10.5430/ijfr.v6n2p67

\begin{abstract}
This study examines how firm's default risk affects the earnings response coefficient (ERC). If accounting earnings provide firm's informativeness, the ERC of the firms highly associated with the default risk. The reason for this is that the firm's bankruptcy risk determines the mechanism allocating wealth changes from unexpected earnings between shareholders and bondholders. Based on that, I investigate the changes of ERCs comparing with the issue of bond and the redemption of issued bond, using a sample of 128 firms in the Korean Stock Exchange (KSE) during 2000-2007 periods. The empirical results indicate that the ERCs decrease for the issue of new bond, whereas increase for the redemption of issued bond, after controlling the market beta and firm's growth ratio. Overall, the findings provide directly support that the ERC is a negatively related to the firm's default risk as measured by financial leverage.
\end{abstract}

Keywords: default risk, earnings response coefficients, financial leverage

\section{Introduction}

This study examines how firm's debt (default risk) affects the relationship between unexpected changes in accounting earnings and stock return. I investigate this issue by examining the changes of the firm's debt on the coefficients (hereafter, earnings response coefficient; ERCs) relating unexpected earnings and abnormal stock returns. In this study, the type of debt changes is considered as the issue of new bond and the redemption of issued bond. If accounting earnings provide firm's informativeness, the ERC of the highly associated with the default risk. The reason for this is that the bankruptcy risk determines the mechanism allocating wealth changes from unexpected earnings between shareholders and bondholders. Dhaliwal, Lee and Fargher (1991) and Dhaliwal and Reynolds (1994) show that financial leverage is effective on ERC, thus default risk negatively affect the ERC. Accordingly, firm's ERC with low default risk is larger than firm with high default risk. Fisher and Verrecchia (1997) and Billings (1999) provide similar results with Dhaliwal and Reynolds (1994). In this study, I examine the influence of default risk on the ERCs by extending the work of previous researches. The empirical results of this study may indicate that the shareholders of high (low) default risk firm will gain or loss less (more) than those of low default risk firm, suggesting a negative relation between the ERC and the default risk.

\section{Literature Review}

The default risk of a bond issue is directly related to the riskiness of the firm's operating activities. Collins and Kothari (1989) find the ERC varies negatively varies with market beta (systematic risk), while positively varies with firm's growth perspective. Shapiro (1990) suggests the issue of new bond can increase default risk, but the redemption of issued bond can decrease default risk. Dhaliwal, Lee and Fargher (1991) conduct the relationship between ERC and effect of financial leverage. They find that ERC with low debt ratio is largher than firms with high debt ratio. Dhaliwal and Reynolds (1994) examine the effect of the default risk of debt between accounting earnings and stock return. Their results suggest that default risk of debt may help to explain how accounting earnings are linked to stock returns and find that ERC is negatively related to the default risk of debt as measured by a ranking of stocks and debt ratios. Cho and Jung (1994) examined the determinants of ERC and evidence that the higher debt and lower growth, the smaller the ERC. Campbell, Hilscher, and Szilagyi (2008) find a negative relation between default risks and stock returns. More recently, Cheng and Nasir (2010) document that earnings have a contemporaneous impact on share prices and risk determinants affect the magnitude of the earnings response coefficients that stock prices change in a significant manner in response to the change of earnings. Moradi, Salehi, 
and Erfanian (2010) investigate the determinant factor of ERC using Iranian firms and show that the ERC for the low leverage firms is largher than the high leverage firms. Zakaria, Isa, Abidin (2013) examines whether default risk has any effect on the earnings response coefficient (ERC) while controlling for the established determinants of ERC beta, growth, earnings persistence and size. They confirm that beta is negatively related to ERC and that default risk is negatively related to ERC. Consequently, changes of capital structure deliver firm's information to stockholders so that the ERCs at the years of capital structure changes may be affected by the default risk related to capital structure changes.

\section{Research Design}

The research question addressed in this study is how firm's default risk systematically affects ERC, measure for the abnormal return in reaction to unexpected earnings. Based on previous researches, the ERC has negative relationship with the firm's default risk association with debt in its capital structure. In order to test this research question, this study examines whether there is any significant difference in the ERCs between periods prior to and subsequent to firms' issue and redemption of bond. In order to measure default risk, the issue of new bond and the redemption of issued bond would have opposite effects on the ERCs. The empirical results may expect that the ERCs have decreased for the issue of new debt, but increased for the redemption of issued debt.

\subsection{Sample Selection}

The sample for the study is consisted of 128 Korean firms listed excluding financial institute in the Korean Stock Exchange (KSE) that experienced either the issue or the redemption of issued bond, during eight year period from 2000 to 2007. The rationale of selecting the sample period (2000-2007) is due to the recent global financial crisis in 2008. The identity of each firm, its capital structure and the year of capital structure change were obtained from KIS-VALUE database provided by the Korean Information Service (KIS). KIS is a credit rating agency in Korea and provides corporate financial information on public firms as well as private and government firms. KIS receives financial information of Korean firms from the Korea Financial Supervisory Board which is subsidiary of Korean government.

\subsection{Cumulative Abnormal Returns (CAR)}

In this study, cumulative abnormal returns $(C A R)$ are measured as accumulating abnormal returns over the twelve months that correspond with the fiscal period. Using Sharp (1963) market model, abnormal normal returns $(A R)$ is measured by actual returns of stock from expected returns of stock. Abnormal returns (AR) are calculated as follows:

$$
A R_{i j}=R_{i j}-\left(\alpha_{i}+\beta_{i} R_{m j}\right)
$$

Cumulative abnormal returns $(C A R)$ is aggregate of the abnormal returns over twelve and calculated as follows:

$$
\mathrm{CAR}_{\mathrm{i}}=\sum \mathrm{AR}_{\mathrm{i}}
$$

\subsection{Unexpected Earnings (UE)}

In order to measure unexpected EPS, the random walk with drift model is assumed as the EPS generation process. For this model, expected EPS can be stated as follows:

$$
E_{t-1}\left(E P S_{t}\right)=E P S_{t-1}+\delta_{t}
$$

where, EPS is earnings per share, and $\delta$ is average EPS for the 5 previous years.

Unexpected Earnings (UE) are calculated by subtracting E(EPS) from actual EPS, and then deflated by total market value of equity at the beginning of the fiscal period. To avoid the problems with outliers, observations with $|\mathrm{UE}|>100 \%$ are excluded. The decision to exclude observations $|\mathrm{UE}|>100 \%$ may seem arbitrary, but it is commonly used in the literature (e.g., Collins and Kothari, 1989; Martikainen, 1997). These observations are few and their deviation from the mean is very high. Therefore the inclusion of these observations in the sample would likely distort the measured return-earnings relation.

\subsection{Empirical Model}

This study investigate that the ERC is negatively associated with the firm's default risk. Default risk is measured by financial leverage changes through either the issue of new bond or the redemption of issued bond. Thus, this study employs the following regression model:

$$
\mathrm{CAR}_{\text {it }}=\alpha+\beta_{1} \mathrm{UE}_{\mathrm{it}}+\beta_{2} \mathrm{RISK} * \mathrm{UE}_{\mathrm{it}}+\beta_{3} \mathrm{GRW} * \mathrm{UE}_{\mathrm{it}}+\mathrm{\gamma D}_{\mathrm{it}} * \mathrm{UE}_{\mathrm{it}}+\epsilon_{\mathrm{it}}
$$

where, $\mathrm{CAR}_{\mathrm{it}}=$ cumulative abnormal returns for firm i in year $\mathrm{t}$; $\mathrm{UE}_{\mathrm{it}}=$ unexpected EPS for firm $\mathrm{i}$ in year; RISK $=$ market beta for firm $\mathrm{i}$ in year $\mathrm{t} ; \mathrm{GRW}_{\mathrm{it}}=$ market value to book value of equity ratio; $\mathrm{D}_{\mathrm{it}}=$ dummy variable which 
takes a value of one if year $\mathrm{t}$ for firm $\mathrm{i}$ is in the post-change period, and zero if year $\mathrm{t}$ is in the pre-change period.

The sign of the estimated coefficient $\gamma$ in above model represents the significant difference in the ERC between default risk changes period. Thus, the sign of $\gamma$ may be negative when new bond is issued, while $\gamma$ may be positive when issued bond is redeemed.

\section{Empirical Results}

\subsection{Descriptive Statistics}

Table 1. Descriptive statistics

\begin{tabular}{cccc}
\hline Variables & Mean & Median & Standard Deviation \\
\hline CAR & 0.049 & 0.031 & 0.593 \\
UE & 0.073 & 0.088 & 0.587 \\
RISK & 1.403 & 0.967 & 0.564 \\
GRW & 1.268 & 0.387 & 6.912 \\
\hline
\end{tabular}

During the sample period, 72 firms issues new bond, whereas 56 firms redeem issued bonds. The average amount for the issue of new bond is KRW 210,846million (equivalent to US\$21million), compared to KRW 98,758million (equivalent to US\$ 9.8million) for the redemption of issued bond. This reflects the economic situation in Korea during 2000-2007 due to high capital demands. Table 1 provides descriptive statistics on selective variables. The mean (median) RISK (market beta) for the sample is 1.149 (0.988), and GRW is from 0.017(0.387), respectively

\subsection{Correlation Analysis}

Table 2. Pearson correlation

\begin{tabular}{ccccc}
\hline Variables & CAR & UE & RISK & GRW \\
\hline CAR & 1 & & & \\
UE & $0.854^{* *}$ & 1 & & \\
RISK & $-0.196^{* * *}$ & $0.217^{* * *}$ & 1 & 1 \\
GRW & $-0.073^{*}$ & 0.467 & -0.068 & 1 \\
\hline
\end{tabular}

Subscripts $* * *$, and $* * *$ indicate statistical significance at $10 \%, 5 \%$, and $1 \%$ levels, respectively

Table 2 presents the correlation among variables. As showing Table 2, CAR has significantly positive correlation with UE and negative correlation with RISK. Negative correlation between UE and GRW is statistically not significant. Small magnitude of correlations among independent variables indicates that multicollinearity is not severe problem in interpreting the coefficient of the regression model.

\subsection{Empirical Results}

Table 3 presents the results of testing whether there are any significant changes in the ERCs when the firm experiences change in its capital structure due to either issue of new bond or redemption of issued bond. The results are reported for two types of capital structure changes, the issue of new bond and the redemption of issued bond. The coefficient is negative for the issue of new bond, but positive for the redemption of issued bond. 
Table 3. Empirical results

$$
\begin{aligned}
& \text { This table presents the results of ordinary least squares(OLS) } \\
& \mathbf{C A R}_{\mathbf{i t}}=\boldsymbol{\alpha}+\boldsymbol{\beta}_{\mathbf{1}} \mathbf{U E}_{\mathbf{i t}}+\boldsymbol{\beta}_{\mathbf{2}} \mathbf{R I S K} * \mathbf{U} \mathbf{E}_{\mathbf{i t}}+\boldsymbol{\beta}_{\mathbf{3}} \mathbf{G R W} * \mathbf{U E}_{\mathbf{i t}}+\boldsymbol{\gamma} \mathbf{D}_{\mathbf{i t}} * \mathbf{U} \mathbf{E}_{\mathbf{i t}}+\boldsymbol{\epsilon}_{\mathbf{i t}}
\end{aligned}
$$

where, $\mathrm{CAR}_{\mathrm{it}}=$ cumulative abnormal returns for firm $\mathrm{i}$ in year $\mathrm{t} ; \mathrm{UE}_{\mathrm{it}}=$ unexpected EPS for firm $\mathrm{i}$ in year; $\mathrm{RISK}_{\mathrm{it}}=$ market beta for firm $\mathrm{i}$ in year $\mathrm{t} ; \mathrm{GRW}_{\mathrm{it}}=$ market value to book value of equity ratio; $\mathrm{D}_{\mathrm{it}}=$ dummy variable which takes a value of one if year $t$ for firm $i$ is in the post-change period, and zero if year $t$ is in the pre-change period.

\begin{tabular}{|c|c|c|c|c|}
\hline \multirow{2}{*}{ Variables } & \multicolumn{2}{|c|}{ Expected Sign } & \multirow{2}{*}{$\begin{array}{l}\text { Model 1: } \\
\text { The Issues of New Bond }\end{array}$} & \multirow{2}{*}{$\begin{array}{l}\text { Model 2: } \\
\text { The Redemption of Issued } \\
\text { Bond }\end{array}$} \\
\hline & Modell & Model2 & & \\
\hline $\mathrm{UE}$ & + & + & $0.352 * * *$ & $0.204 * * *$ \\
\hline RISK*UE & - & - & $-0.071^{*}$ & $-0.125^{*}$ \\
\hline $\mathrm{GRW} * \mathrm{UE}$ & + & + & $0.132 *$ & $0.301 *$ \\
\hline $\mathrm{D} * \mathrm{UE}$ & - & + & $-0.024 * *$ & $0.292 * *$ \\
\hline Constant & $?$ & $?$ & $-0.649 * * *$ & $-0.521 * * *$ \\
\hline \multicolumn{3}{|c|}{ Adjusted $R^{2}$} & 0.188 & 0.146 \\
\hline \multicolumn{3}{|c|}{ F-Statistics } & $28.013^{* * *}$ & $26.794 * * *$ \\
\hline
\end{tabular}

Subscripts *,**, and *** indicate statistical significance at $10 \%, 5 \%$, and $1 \%$ levels, respectively

The control variables, RISK and GRW, have been shown to affect ERCs (e.g., Easton and Zmijewski 1989 and Collins and Kothari 1989). The coefficients of the issue of new bond on RISK (-0.071) and GRW (0.132) have their predicted signs and statistically significant at 0.10 levels. Likewise the issue of new bond, the coefficients of the redemption of issued bond on RISK (-0.125) and GRW (0.301) shows the same results with the issue of new bond at 0.10 levels, respectively. The estimation results are consistent with the previous research and expectation when capital structure is changed through the issue of new bond and redemption of issued bond on Korea. When new bond is issued, the ERC is 0.352 as well as 0.204 in redemption of issued bond, respectively. The estimation results are consistent with the previous research andl prediction when capital structure is changed through the issue of new bond. This decrease in the ERC is reported in the negative value of the regression coefficient $\gamma$. As well, the coefficient $\gamma$ has negative (-0.024) and statistically significant at 0.05 level. For redemption of issued, as shown in Table 2, there are significant changes in capital structures even after the redemption. Therefore, for the redemption of issued bond sample, it is expected that the estimated coefficient $\gamma$ has the positive sign, which is consistent with the theoretical prediction. As predicted, the coefficient of dummy variable is positive $(0.292)$ and statistically significant at 0.05 level. This result provides a direct support to the expectation that the ERC is negatively related to default risk.

Overall, these results strongly support to the expectation that the ERC is a negative function of a firm's default risk.

\section{Discussion}

This study examines how firm's debt (default risk) affects the relationship between unexpected changes in accounting earnings and stock return. From empirical results, I find that the ERC has a negative relationship with the firm's default risk. Using a sample of 128 firms listed in the Korean Stock Exchange (KSE) that experienced either the issue of new bond or the redemption of issued bond during 2000-2007 periods, this study compares the ERCs between the firms experienced capital structure changes.

The empirical results support that the ERCs decrease for the issue of new bond, whereas increase for the redemption of issued bond. These movements of the ERCs are statistically significant after controlling market beta and firm's growth ratio. These results confirm previous research that the firm's default risk is an important factor to determine the ERCs.

There some limitations in this study. First, as a measure of default risk, shift in default risk (change in capital structure) might be weak proxy to test the effect on the ERC. In the further study, better proxy for the firm's default risk could be considered. Second, changes in financial leverage of large Korean firms so called Chaebol may not reflect the changes in the default risk because of cross-guarantee of debt across the firms with Chaebol groups in 
Korea.

There are some issues left for future research. First, additional testing of the 'default risk effect' can be conducted by using the sample of firms that have experienced changes in their bond ratings. To the extent that bond ratings are better proxy for the default risk, the use of bond rating instead of financial leverage will enhance the chance of observing the effect of default risk on the ERCs. Second, it can be examined by some analysis which considers more complex capital structures such as those consisting of convertible debt or convertible preferred stocks. Because the existence of some types of claims ultimately affect the net assets distributed to equity holders, one should naturally expect capital structure to influence the relation between earnings and stock returns.

\section{References}

Campbell, John Y., Jens Hilscher, \& Jan Szilagyi. (2008). In search of distress risk. Journal of Finance, 63, 2899-2939. http://dx.doi.org/10.1111/j.1540-6261.2008.01416.x

Cheng, \& Nasir. (2010). Earning Response Coefficients and the Financial Risks of China Commercial Banks. International Review of Business Research Papers, 6(3), 178-188.

Cho, J., \& Jung, K. (1991). Earnings Response Coefficients: a synthesis of theory and empirical evidence. Journal of Accounting Literature, 85-116.

Christie, A. (1987). On Cross-sectional Analysis in Accounting Research. Journal of Accounting and Economics, 231-258. http://dx.doi.org/10.1016/0165-4101(87)90007-3

Collins, D., \& Kothari, S. (1989, July). An Analysis of Intertemporal and Cross-sectional Determinants of Earnings Response Coefficients. Journal of Accounting and Economics, 143-181. http://dx.doi.org/10.1016/0165-4101(89)90004-9

Dhaliwal, D., \& Reynolds, S. (1994). The Effect of the Default Risk of Debt on the Earnings Response Coefficient. Accounting Review, 412-419.

Dhaliwal, D., Lee, K., \& Fargher, N. (1991). The Association Between Unexpected Earnings and Abnormal Security Returns in the Presence of Financial Leverage. Contemporary Accounting Research, 20-41. http://dx.doi.org/10.1111/j.1911-3846.1991.tb00832.x

Easton, P., \& Zmijewski, M. (1989). Cross-sectional Variation in the Stock Market Response to Accounting Earnings Announcements. Journal of Accounting and Economics, http://dx.doi.org/10.1016/0165-4101(89)90003-7

Freeman, R. (1987). The Association between Accounting Earnings and Security Returns for Large and Small Firms. Journal of Accounting and Economics, 195-228. http://dx.doi.org/10.1016/0165-4101(87)90005-X

Kormendi, R., \& Lipe, R. (1987). Earnings Innovations, Earnings Persistence, and Stock Returns. Journal of Business, 323-345. http://dx.doi.org/10.1086/296400

Martikainen, M. (1997). Accounting Losses and Earnings Response Coefficients: The Impact of Leverage and Growth pportunities. Journal of Business Finance and Accounting, 24(2), $277-291$. http://dx.doi.org/10.1111/1468-5957.00105

Miller, M., \& Modigliani, F. (1961). Dividend Policy, Growth and the Valuation of Shares. Journal of Business, 411-433. http://dx.doi.org/10.1086/294442

Miller, M., \& Rock, K. (1985). Dividend Policy Under Asymmetric information. Journal of Finance, $1031-1052$. http://dx.doi.org/10.1111/j.1540-6261.1985.tb02362.x

Moradi, M., Salehi, M., \& Erfanian, Z. (2010). A Study of the Effect of Financial Leverage on Earnings Response Coefficient throug out Income Approach: Iranian Evidence. International Review of Accounting, Banking and Finance, 103-115.

Nor Balkish Zakaria, Mohamad Azwan bin Md Isa, \& Rabiatul Alawiyah Zainal Abidin. (2013). Default risk and the earnings response coefficient. Evidence from Malaysia. Journal of Basic and Applied Scientific Research, 3(6), $535-545$.

Shapiro, A. (1990). Modern Corporate Finance. Macmillan. 